\title{
HAKIKAT PENDIDIKAN DI LEMBAGA PEMBINAAN KHUSUS ANAK
}

\author{
Gunaldi Ahmad \\ (gunaldiahmad.stit@gmail.com) \\ Dosen Universitas Islam Negeri (UIN) Syarif Hidayatullah Jakarta
}

\begin{abstract}
Abstrak: Perubahan terus terjadi pada penanganan dan pembinaan anak-anak nakal di Indonesia. Peraturan tata laksana pembinaan terus dilakukan. Dari Undang-undang No 3 tahun 1997 tentang Undang-undang Peradilan Anak saat diubah menjadi Undang-undang No 11 Tahun 2012 Tentang Sistem Peradilan Pidana Anak. Karakteristik undang-undang yang relatif baru ini memiliki karakteristik utama yakni memberikan perlindungan kepada anak yang bermasalah dengan hukum serta sesuai dengan Konvensi Hak-Hak Anak. Pendidikan di LPKA sudah terlaksana dengan segala keterbatasan serta mampu membawa perubahan perilaku anak pemasyarakatan untuk lebih baik maka pendidikan dapat mengembalikan jati diri anak. Pendidikan yang diselenggarakan di Lembaga Pembinaan Khusus Anak diharapkan dapat mencapai cita-cita "anak" agar lebih bermanfaat setelah selesai menjalani pendidikan di Lembaga Pembinaan Khusus Anak. Selanjutnya LPKA ditantang untuk melakukan modernisasi dalam bidang pendidikan.
\end{abstract}

Kata Kunci: Pendidikan, Lembaga Penbinaan Khusus Anak

\section{A. Pendahuluan}

Pendidikan yang diberikan kepada siswa berlatar sosial dan hukum bermasalah atau bermasalh dengan hukum atau istilahnya lainnya anak yang berhadapan dengan hukum/anak berkonflik dengan hukum cenderung lebih sulit. Sementara pandangan bahwa lembaga pemasyarakatan (LP) masih dianggap sekolah tinggi kejahatan belum luntur di masyarakat. Jika hal ini terus tidak ada solusi akan membawa kehancuran generasi muda. Maka sejatinya pendidikan tidak boleh meninggalkan generasi muda yang bermasalah dalam kondisi apapun. Disatu sisi muncul pertanyaan tentang efektivitas penyelenggaraan pendidikan formal di lembaga pemidanaan, termasuk salah satunya di LPKA, misalnya LPKA Klas 1 Tangerang. Secara pendidikan yang dilakukan di LPKA adalah pendidikan saat anak-anak menjalani tindakan dan menlani Pidana skala usia 12-18 tahun. Dalam pidana bersyarat maka anak harus mengikuti wajib belajar 9 (sembilan) tahun. Sebabnya adalah penyelenggaraan pendidikan formal dengan segala perangkatnya memerlukan perhatian yang sangat kompetitif dan inovatif. 
ISTIGHNA, Vol. 1, No 1, Januari 2018 P-ISSN 1979-2824

Homepage: http://e-journal.stit-islamic-village.ac.id/index.php/istighna

Gunaldi Ahmad

Hakikat Pendidikan di Lembaga Pembinaan Khusus Anak

Istilah pendidikan dalam konteks Islam pada umumya mengacu pada term tarbiyah, a;-ta'dib dan al-ta'lim. Dari ketiga istilah tersebut term yang populer digunakan dalam praktek pendidikan Islam adalah term al-tarbiyah. Sedangkan term alta'dib dan al-ta'lim jarang digunakan. Istilah tarbiyah berasal dari kata rabb. Pengertian dasarnya memiliki makna dasar tumbuh, berkembang, memelihara, merawat, mengatur dan menjaga kelestarian dan eksistensinya. Selanjutnya istilah al-ta'lim. Muhammad Rashid Ridha mengartikan al-ta'lim sebagai proses transmisi berbagai ilmu pengetahuan pada jiwa individu tanpa adanya batasan dan ketentuan tertentu. Dan istilah al-ta'dib dimaknai dengan mendidik. Al-ta'dib berarti pengenalan dan pengakuan yang secara berangsur angsur ditanamkan ke dalam diri manusia (peserta didik), tentang tempat-tempat tepat dari segala sesuatu di dalam tatanan penciptaan. Dengan pendekatan ini, pendidikan akan berfungsi sebagai pembimbing ke arah pengenalan dan pengakuan tempat Tuhan yang dalam tatanan wujud dan kepribadiannya. ${ }^{93}$

Pendidikan adalah usaha sadar dan terencana untuk mewujudkan suasana belajar dan proses pembelajaran agar peserta didik secara aktif mengembangkan potensi dirinya untuk memiliki kekuatan ritual keagamaan, pengendalian diri, kepribadian, kecerdasan, akhlak mulia, serta keterampilan yang diperlukan dirinya, masyarakat, bangsa dan negara. ${ }^{94}$ Wajib Belajar adalah program pendidikan minimal yang harus diikuti oleh warga negara atas tanggung jawab pemerintah dan pemerintah daerah. ${ }^{95}$ Standar nasional pendidikan adalah kriteria minimal sistem pendidikan di seluruh wilayah hukum Negara Kesatuan Indonesia. ${ }^{96}$ Pembelajaran adalah proses interaksi peserta didik dengan pendidik dan sumber belajar pada suatu lingkungan belajar. ${ }^{97}$

Pendidikan merupakan masalah yang tidak pernah selesai (unfinished agenda). ${ }^{98}$ Salah satu yang menjadi sorotan adalah apakah anak yang dibina dalam Lembaga Pembinaan Khusus Anak mendapat pendidikan yang layak?

\footnotetext{
${ }^{93}$ Al-Rasyidin dan Samsul Nizar, Pendekatan Teoritis dan Praktis Filsafat Pendidikan Islam, (Ciputat: Rajawali Press, 2005), Cet. Ke- 2.

${ }^{94}$ Fokusmedia, Undang-undang Sisdiknas (Sistem Pendidikan Nasional) (Bandung: Fokusmedia: 2010), h. 2.

${ }^{95}$ Ibid

${ }^{96}$ Ibid.

${ }^{97}$ Ibid.

98 Ahmad Tafsir, Filsafat Pendidikan Islami, Integrasi Jasman, Rohani dan Kalbu Memanusiakan Manusia, (Bandung: PT. Remaja Rosdakarya, 2006), h. 40.
} 
ISTIGHNA, Vol. 1, No 1, Januari 2018 P-ISSN 1979-2824

Homepage: http://e-journal.stit-islamic-village.ac.id/index.php/istighna

Gunaldi Ahmad Hakikat Pendidikan di Lembaga Pembinaan Khusus Anak

Dimana tempatnya apakah di Lembaga Pembinaan Khusus Anak? Apakah pendidikan yang diberikan memenuhi sistem pendidikan nasional? Dan apakah pendidikan yang diberikan di LPKA bisa menjangkau hakikat pendidikan? Berdasarkankan latar belakang tersebut di atas penulis akan meneliti Hakikat Pendidikan di Lembaga Pemasyarakatan Anak

\section{B. Pendidikan di Lembaga Khusus Pembinaan Anak.}

1. Sejarah Lembaga Khusus Pemidanaan Anak di Indonesia

Pasal 61 ayat 2 Undang-Undang No 3 Tahun 1997 tentang Peradilan Anak menyebutkan: Anak yang ditempatkan di lembaga sebagaimana dimaksud dalam ayat (1) berhak memperoleh pendidikan dan latihan sesuai bakat dan kemampuannya serta hak lain berdasarkan peraturan perundangundangan yang berlaku. ${ }^{99}$ Dalam sejarahnya setelah pergantian undangundang kebijakan pemerintah RI tentang pendidikan formal bagi anak pidana diatur melalu Undang-undang No 11 Tahun 2012 Tentang Sistem Peradilan Pidana Anak Pasal 82 (1): Tindakan yang dapat dikenakan kepada Anak meliputi: a. pengembalian kepada orang tua/Wali; b. penyerahan kepada seseorang; c. perawatan di rumah sakit jiwa; d. perawatan di LPKS; e. kewajiban mengikuti pendidikan formal dan/atau pelatihan yang diadakan oleh pemerintah atau badan swasta; f. pencabutan surat izin mengemudi; dan/atau g. perbaikan akibat tindak pidana. ${ }^{100}$

Selanjutnya pasal 9 ayat 1 Undang-undang No. 23 Tahun 2002 Tentang Perlindungan Anak menyatakan: "Setiap anak berhak memperoleh pendidikan dan pengajaran dalam rangka pengembangan peribadinya dan tingkat kecerdasannya sesuai dengan minat dan bakatnya. ${ }^{101}$

Hal yang diperoleh Anak Didik Pemasyarakatan selama ditempatkan di Lembaga pemasyarakatan Anak sesuai dengan ketentuan Undang-undang Nomor 12 Tahun 1995 tentang Pemasyarakatan. Dalam pemberian hak

\footnotetext{
${ }^{99}$ Redaksi Sinar Grafika, Undang-Undang Peradilan Anak, No. 3 Tahun 1997, (Jakarta: Sinar Grafika, 1997), h.25.

100 www Hukum Online com, Undang-undang No 11 Tahun 2012 Tentang Sistem Peradilan Pidana Anak, (accses, 2 Juli 2018), h. 38

${ }^{101}$ Redaksi Sinar Grafika, Undang-Undang Perlindungan Anak (UU No. 23 Tahun 2002), (Jakarta Sinar Grafika, 2003), h. 6
} 
ISTIGHNA, Vol. 1, No 1, Januari 2018 P-ISSN 1979-2824

Homepage: http://e-journal.stit-islamic-village.ac.id/index.php/istighna

Gunaldi Ahmad Hakikat Pendidikan di Lembaga Pembinaan Khusus Anak

tersebut tetap perlu diperhatikan pembinaan bagi anak yang bersangkutan antara lain mengenai pertumbuhan dan perkembangan fisik, mental, maupun sosial anak. ${ }^{102}$ Penerapan aturan pembinaan anak diatur secara khusus melalui Undang-undang No. 3 Tahun 1997 yang kemudian diubah menjadi menjadi Undang-undang No 11 Tahun 2012 Tentang Sistem Peradilan Pidana Anak. Istilah bagi nakal di UU No. 3 Tahun 1997 dari "Anak Pidana "kemudian dalam UU No. 11 Tahun 2012 menjadi "Anak" (anak yang menjalani pidana. Sebutan Anak Negara dan Anak Sipil Undang-undang No. 3 Tahun 1997 dihapus. Karena yang masuk ke LPKA sesuai UU No. 11 Tahun 2012 hanya anak yang menjalani masa pidana saja.

Dengan demikian sebenarnya Lembaga Khusus Pembinaan Anak mengalami evolusi dari masa kemasa. Dahulu pemerintah Hindia Belanda abad ke-19 masih memperlakukan seseorang yang melakukan kejahatan secara umum dengan pendekatan dari sisi objek pemindanaan saja. Artinya pelanggaran dan kejahatan akan menentukan apa hukuman yang akan diterima. Jadi tindakan kejahatan (tindak pidana) berhubungan langsung dengan jenis hukuman yang harus diterima pelaku. Perubahan sikap pemerintah Hindia Belanda ini mulai melunak awal abad ke 20 dengan ditandai pendekatan pada subjek pada pemidanaan. Artinya hukuman yang diberikan tidak serta merta diterapkan tanpa memandang jenis kelamin pelaku, usia pelaku dan sebagainya. Dari sini penulis meperoleh landasan filosofis perlunya pemerintah Hindia Belanda memandang perlu pemisahan lokasi hukuman (penjara) bagi kejahatan dan pelanggaran yang dilakukan oleh anak dengan pelanggaran dan kejahatan yang dilakukan orang dewasa. Keinginan pemerintah merivitalisasi sarana prasarana lembaga pemasyarakatan dengan memperbahauri tempat dan manajemen lembaga pemasyarakatan.

Dahulu di masa penjajahan Belanda, anak-anak atau sebutannya "anak muda usia" disatukan dengan terpidana dewasa dalam satu lokasi penjara, namun seiring modernisasi pemidanaan di Belanda. Pemerintahan Hindia ${ }^{102}$ Ibid. 
ISTIGHNA, Vol. 1, No 1, Januari 2018 P-ISSN 1979-2824

Homepage: http://e-journal.stit-islamic-village.ac.id/index.php/istighna

Gunaldi Ahmad Hakikat Pendidikan di Lembaga Pembinaan Khusus Anak

Belanda terus melakukan perubahan. Wagiati Soerojo mengungkapkan bahwa dasar hukum mendirikan lembaga khusus bagi terpidana anak muda usia adalah sejak berlakunya kitab hukum pidana khusus bagi Hindia Belanda yakni Weetboek van Strafrecht vor Nerlandsch Indie pada tahun 1918. Selanjutnya pada tanggal 25 Juli 1921 Direktur Justice (Dirjen kehakiman) mengeluarkan surat edaran Nomor 6.141/1 yang berbunyi sebagai berikut: Agar sifat memperbaiki dari hukuman lebih nyata manfaatnya dan untuk itu sejauh mungkin perlu dicegah jatuhnya yang masih muda usia diantara terpidana ke lembah kehancuran karena selama mengalami pidananya terus menerus bergaul dengan penjahat-penjahat ulung, maka dipandang perlu mengadakan klasifikasi yang lebih efektif daripada yang telah berlangsung sebelumnya. Langkah pertama yang terpenting sehubungan dengan ini ialah pendirian sebuah lembaga khusus untuk terpidana yang masih dianggap masih belum dewasa. Sambil menunggu dibangunnya lembaga khusus untuk terpidana "muda usia" memenuhi persyaratan maka dengan ini diputuskan untuk mempergunakan bangunan penjara kota Madiun yang lama guna keperluan tersebut. Di lembaga yang masih cukup memenuhi persyaratan ini para terpidana muda usia akan dipekerjakan di bawah pimpinan yang khusus dipilih untuk keperluan itu, sehingga terpidana yang bersangkutan mampu mencari nafkah yang halal setelah bebas. Sehubungan dengan hal tersebut di atas dimohon dengan hormat supaya untuk selanjutnya, mulai 01 Agustus 1918 yang akan datang semua terpidana laki-laki putusan pengadilan negeri (Landraad Veroordelen) di bawah umur 19 tahun (yakni baik yang dikenakan pidana berdasarkan pasal 45 KUHP yang berumur 16 tahun, maupun yang dikenakan pidana berumur 16 tahun sampai 18 tahun saja yang sisa pidananya sedikit-dikitnya 6 bulan setelah vonisnya boleh dapat dijalankan segera dikirim ke penjara lama di Madiun sebagaimana yang dimaksudkan. ${ }^{103}$

${ }^{103}$ Wagiati, Soetodjo, Hukum Pidana Indonesi, (Bandung: Reflika Aditama, 2006), h. 86- 
ISTIGHNA, Vol. 1, No 1, Januari 2018 P-ISSN 1979-2824

Homepage: http://e-journal.stit-islamic-village.ac.id/index.php/istighna

Gunaldi Ahmad Hakikat Pendidikan di Lembaga Pembinaan Khusus Anak

Wagiati Soetodjo dalam bukunya menegaskan bahwa rumah penjara untuk "muda usia" atau anak nakal pertama ada di kota Madiun. Motto penjara untuk muda usia waktu itu adalah: "Penjara untuk perbaikan" (Verbentering Gevagens). Dari sisi falsafah tersebut maka pemerintah Hinda Belanda merasa penjara kota Madiun tidak lagi memadai. Pemerintah Hindia Belanda memutuskan untuk merevitalisasi penjara. Maka penjara untuk "muda usia" dipindahkan ke kelurahan Tanah Tinggi Kecamatan Tangerang, kota Tangerang. Waktu itu pemerintah Hindia Belanda membeli tanah milik swasta dan mendiirikan Rumah Penjara untuk "anak muda usia" rumah Lembaga Pendidikan Negara untuk anak laki-laki, dan sebuah Lembaga Pendidikan Negara untuk wanita yang dimulai pada tanggal 18 Juli 1992. Dalam pengerjaan tiga lembaga pemasayarakatan khusus anak dan wanita di kota Tangerang dilakukan dengan memanfaatkan tenaga terpidana "muda usia" di bawah pimpinan bagian urusan Bangunan dan Lembaga khusus untuk terpidana "muda usia" Tanggal 28 Desember 1923 sampai tahun 1925 dua bangunan yakni rumah penjara untuk "anak muda usia" dan rumah Lembaga Pendidikan Negara untuk anak laki-laki. Bentuk lembaga khusus anak di Tangerang dibuat dengan sistem bangunan paviliun (cottage sistem) dengan tujuan untuk menciptakan suasana kekeluargaan. Adapun penjara khusus wanita baru dilakukan pembagunannya pada tahun $1925 .^{104}$

Secara garis besar penjara anak sebagai wadah menampung dan memperbaiki anak nakal dibuka tahun 1928 yang diurus oleh pemerintah Hindia Belanda. Kemudian tahun 1934 pengurusan penjara anak diurus oleh badan swasta (pra juveneli). Ketika Indonesia di kuasa Jepang, maka penjara anak diurus oleh pemerintah Nippon, tahun 1950 pengurusan lembaga penjara anak dilakukan oleh lembaga swasta Pra Yuwana, dan terakhir pada tahun 1960 hingga sekarang lembaga penjara anak diurus oleh pemerintah Republik Indonesia. Sejak tahun 1960, istilah penjara anak

${ }^{104}$ Ibid, h. $87-88$ 
ISTIGHNA, Vol. 1, No 1, Januari 2018 P-ISSN 1979-2824

Homepage: http://e-journal.stit-islamic-village.ac.id/index.php/istighna

Gunaldi Ahmad

Hakikat Pendidikan di Lembaga Pembinaan Khusus Anak

diganti menjadi Lembaga Pemasyarakatan Anak. ${ }^{105}$ Saat ini nama Lembaga Pemasyarakatan Anak sudah berubah dengan nama Lembaga Pembinaan Khusus Anak. Pada tanggal 5 Agustus 2015 LP Anak Pria Tangerang berubah nama menjadi Lembaga Pembinaan Khusus Anak (LPKA) yang berlaku di seluruh Indonesia. ${ }^{106}$

2. Lembaga Pembinaan Khusus Anak Kelas 1 Tangerang dan Pendidikan Formal.

Pada awalnya belum ada pendiidkan formal di LPKA, yang ada baru "LPKBM Istimewa" yang diberi izin Menteri Pendidikan Nasional untuk mengeluarkan paket A, B dan C. Lembaga Pembinaan Khusus Anak Kelas 1 Tangerang juga memiliki pesantren. Begitu juga dengan diadakannya Taman Baca Masyarakat. ${ }^{107}$

Untuk membina usaha kesadaran berbangsa dan bernegara maka Lembaga Pembinaan Anak Tangerang yang sekarang berganti nama Lembaga Pembinaan Anak terus melakukan pembinaan kesadaran

${ }^{105}$ Ibid, h. 92

${ }^{106}$ Blogspot.co.id, Lembaga Pembinaan Khusus Anak Klas I Tangerang, diakases Selasa 12 April 2016) berikut ini dijelaskan visi dan misi Lembaga Pembinaan Khusus Anak Klas 1 Tangerang;

Visi: Menjadi institusi terpercaya dalam memberikan pelayanan, perlindungan, pembimbingan, pembinaan dan pendidikan Anak Didik Pemasyarakatan.

Misi:

1) Mewujudkan sistem perlakuan kreatif yang menumbuhkan rasa aman, nyaman, ramah dan layak anak.

2) Melaksanakan perawatan, pelayanan, pendidikan, pembinaan, dan pembimbingan untuk kepentingan terbaik bagi anak.

3) Membentuk jiwa sportifitas dan cinta ilmu pengetahuan bagi anak.

4) Menumbuhkembangkan ketakwaan, kesantunan, kecerdasan, rasa percaya diri dan keceriaan anak.

5) Memberikan perlindungan, pelayanan dan pemenuhan hak anak.

Lokasi LPKA Klas I Tangerang, terletak di Jln. Daat Mogot No. 29 C. Bangunan Tersebut berbatasan dengan mesjid Azhom di sebelah Selatan, Taman Makam Pahlawan Taruna di sebelah Barat, Jalan Daat Mogot di sebelah Utara dan jalan Satria Sudirman di sebelah Timur. Lapas Anak Pria Tangerang di bangun pada masa Hindia Belanda pada tahun 1925, dengan kapasistas hunian 220 anak, sejak tahun 1934 pengelolaan lapas ini di serahkan kepada Pro Juventute untuk mengasingkan anak keturunan Belanda yang berbuat nakal. Perubahan fungsi dari lapas menjadi markas Resimen IV Tangerang terjadi pada tahun 1945. Pada tahun 1957-1961, pengelolaan berganti kepada Kepenjaraan, yang kemudian berubah menjadi pendidikan negara. Di tahun 1964, pengelolaan bangunan diserahkan kepada Direktorat Jenderal Pemasyarakatan dengan nama Lembaga Pemasyaraktan Anak Pria. Bangunan lembaga Pemasyarakatan berada di tanah milik negara seluas $12.150 \mathrm{M} 2$.

${ }_{107}$ Wawancara dengan Rizal Hamdi, Plh Kepala LPKA Klas 1 Tangerang), Rabu, 21 Desember 2016 
ISTIGHNA, Vol. 1, No 1, Januari 2018 P-ISSN 1979-2824

Homepage: http://e-journal.stit-islamic-village.ac.id/index.php/istighna

Gunaldi Ahmad Hakikat Pendidikan di Lembaga Pembinaan Khusus Anak

berbangsa dan bernegara, usaha tersebut diwujudkan dengan langkah nyata yakni memberikan kesempatan seluas-luasnya memberikan peningkatan kemampuan berfikir dengan pendidikan forman (tingkat SD, SMP, SLTA) seseuai peraturan pemerintah. ${ }^{108}$ Dengan demikian di Lembaga Pembinaan Anak resmi ada sekolah.

Baru pada masa berikutnya pendidikan formal diselenggarakan lansung di LPKA Tangerang. Rizal Hamdi menjelaskan Lembaga Pembinaan Khusus Anak Kelas 1 Tangerang pada tahun pelajaran 20162017, memiliki 70 siswa, yang tersebar di tingkat pendidikan SD, SMP dan SMK. Nama sekolah diberikan dengan nama 'Istimewa (SD Istimewa, SMP Istimewa, dan SMK Istimewa).

Tenaga pengajar baik pada tingkatan SD, SMP dan SMK terdiri dari Guru dari Dinas Pendidikan Kota Tangerang (khususnya untuk SMK) yakni pada mata pelajaran tertentu. Guru dari pegawai/staf Lembaga Pembina Khusus Anak, serta Relawan. Semua guru-guru yang disebutkan di atas bersifat volunter (tanpa ada gaji tetap). Berikut ini penulis jelaskan ringkasan kegiatan belajar mengajar di SD, SMP dan SMK Istimewa di LPKA Tangerang tahun 2016:

\section{a. Tingkat SD}

Pada Tingkatan SD guru-guru yang mengajar banyak diambil dari staf karyawan dari Lembaga Pembinaan Khusus Anak. Khusus siswa SD bisa dilakukan kenaikan tingkat (lompat kelas) sesuai kemampuan dan usia mereka. Karena ada kasus anak yang sudah berusia belasan tahun namun belum SD. Pemberian raport seperti biasa dan Ujian Nasional diselenggarakan di Lembaga Pembinaan bekerjasama dengan SDN 5 Kota Tangerang.

b. Tingkat SMP

Pada tingkatan SMP guru-guru yang mengajar mayoritas diambil dari staf/karyawan Lembaga Pembinaan Khusus Anak. Pemberian raport

\footnotetext{
${ }^{108}$ Wagiati Soetodjo, Hukum Pidana Indonesia, Op.Cit., h. 114.
} 
ISTIGHNA, Vol. 1, No 1, Januari 2018 P-ISSN 1979-2824

Homepage: http://e-journal.stit-islamic-village.ac.id/index.php/istighna

Gunaldi Ahmad Hakikat Pendidikan di Lembaga Pembinaan Khusus Anak

seperti biasa dan UN diselenggarakan di Lembaga Pembinaan bekerjasama dengan SMPN 2 Kota Tangerang.

c. Tingkat SMK

Demikian pula dengan SMK guru-guru yang mengajar mayoritas diambil dari staf/karyawan di Lembaga Pembinaan Khusus Anak. Pemberian raport seperti biasa dan UN diselenggarakan di Lembaga Pembinaan bekerjasama dengan SMKN 2 Kota Tangerang. ${ }^{109}$

Dalam pembinaan anak di Lembaga Pembinaan Khusus Anak bertujuan agar tercapai tujuan pendidikan itu sendriri yakni; membangun aspek kognitif, Afektif dan Psikomotorik. Khusus di Lembaga Pembinaan Khusus Anak Kelas 1 Tangerang, pola pendidikan itu dipengaruhi oleh kebutuhan anak, dan latar belakang anak itu sendiri, pada rentang tahun 2016 ini warga pembinaan anak mayoritas dihunoleh warga Banten dan sekitarnya. Kemudian disusul oleh warga DKI Jakarta. ${ }^{110}$

Pencapaian kognitif, afektif dan psikomotorik ini diberikan kepada siswa pembinaan secara proporsional, selanjutnya ditopang dengan pemberian skill sebagai bekal mereka ditengah-tengah masyarakat. ${ }^{111}$ Pada tahapan kegiatan belajar mengajar (KBM), lembaga pendidikan yang diselenggarakan oleh Lembaga Pembinaan Khusus Anak harus mengikuti sistem pendidikan yang berlaku di Indonesia. Dengan demikian sudah seharusnya pendidikan yang dikelolah oleh Kementerian Hukum dan Hak Azazi Manusia, harus terus berintegrasi dengan memberdayakan tenaga kependidikan dan non kependidikan yang menyelenggarakan pendidikan. Sistem pendidikan nasional adalah keseluruhan komponen pendidikan yang saling terkait guna mencapai tujuan pendidikan nasional. Uji kompetensi siswa harus dilakukan. SD, SMP, SMK yang ada di Lembaga Pembinaan Khusus Anak seharusnya mempunyai sistem akreditasi pula. Dengan demikian diharapkan guru-guru yang mengajar di SD, SMP dan SMK

${ }^{109}$ Ibid.

${ }^{110}$ Wawancara dengan Rizal Hamdi, Plh Kepala LPKA Klas 1 Tangerang), Rabu, 21 Desember 2016

${ }^{111}$ Ibid. 
ISTIGHNA, Vol. 1, No 1, Januari 2018 P-ISSN 1979-2824

Homepage: http://e-journal.stit-islamic-village.ac.id/index.php/istighna

Gunaldi Ahmad Hakikat Pendidikan di Lembaga Pembinaan Khusus Anak

Istimewa khususnya di Lembaga Pembinaan Anak Tangerang sekarang memiliki kompetensi mengajar. Memang ada kesulitan tersendiri untuk memenuhi kempetensi guru seperti ini, karena secara umum tenaga guru untuk SD, SMP dan SMK Istimewa itu diambil dari karyawan LPKA.

Dengan demikian harus ada kemauan kuat dari Kementerian Hukum dan Hak Azazi Manusia memberikan pembaruan pendidikan anak di Lembaga Pembinaan Anak di Tangerang dan LPKA yang di seluruh Indonesia. Oleh sebab itu Kementerian Pendidikan dan Kebudayaan diharapkan melakukan monitoring terpadu antar kementrian terhadap proses pelaksanaan pendidikan di LPKA. Tentu harapannya adalah ada kemauan kementerian pendidikan mensuplai guru-guru professional ke LPKA, atau memberikan latihan tentang ilmu (ilmu pedagogi) pendidikan terhadap karyawan LPKA. Dengan demikian managemen LPKA yang diberi tanggung jawab pembinaan dan juga diberi tugas lain yakni pendidikan anak LPKA mampu menjalankan amanah mencerdaskan kehidupan bangsa dengan baik.

Jika pelaksanaan tugas pembinaan dan tugas pendidikan bagi anak LPKA berjalan baik berarti pihak manajemen LPKA telah melaksanakan amanah yang tertera pada pasal 13 UU No 23 Tentang Perlindungan Anak. ${ }^{112}$ Lembaga Pendidikan Khusus Anak mulai terbuka karena terus menjalin kerjasama dengan lembaga pendidikan lainnya di luar Lembaga mereka.

Sistem akreditasi di SMK selama ini menggunakan sistem Monitoring dan Evaluasi (ME) yang dilaksanakan Tim Dikmenjur, dengan unit analisis sekolah. Setiap SMK memiliki nilai ME masing-masing, misalnya SMK A

112 Pasal 13 UU NO. 23 Tahun 2001 menjelaskan bahwa: Setiap anak seama dalam pengasuhan orang tua, wali, atau pihak lain manapun bertanggung jawab atas pengawasan dan perlindungan dari; a. diskriminasi, b. eksploitasi, c. penelantaran, d. kekejaman, kekerasan/ringan , e. Ketidakadian dan f. Perlakuan yang salah. 
ISTIGHNA, Vol. 1, No 1, Januari 2018 P-ISSN 1979-2824

Homepage: http://e-journal.stit-islamic-village.ac.id/index.php/istighna

Gunaldi Ahmad

Hakikat Pendidikan di Lembaga Pembinaan Khusus Anak

memperoleh nilai AB (Amat Baik), SMK B memperoleh nilai B (Baik) dan SMK C memperoleh nilai C (Cukup). ${ }^{113}$

Sistem Monitoring dan Evaluasi ini seharusnya dapat diterapkan pada pendidikan formal di semua LPKA. Penulis dalam observasi lapangan menumukan bahwa setiap tingkatan sekolah (SD, SMP dan SMK Istimewa) khususnya LPKA Klas 1 Tangerang dipimpin oleh Kepal Sekolah. Sarana belajar mengajar terdiri dari ruang belajar, ruang praktek otomotif untuk SMK, ruang kesenian, ruang pustaka, ruang ibadah. Dan sesuai pengamatan penulis ruang belajar masih cukup dan representatif. ${ }^{114}$ Menurut bapak Sino hal yang masih kurang dan sangat perlu adalah laboratorium untuk belajar bagi mata pelajaran fisika, IPA perlu untuk SMP dan SMK ${ }^{115}$

Selanjutnya menurut penulis pihak manajemen sekolah di LPKA harus dapat memberikan motivasi tinggi kepada anak LPKA yang mengikuti pendidikan formal. Guru yang mengajar di LPKA harus mampu membangkitkan motivasi anak di LPKA dalam belajar. Guru di LPKA harus mampu memvisualisasikan kesuksesan jika mau dan rajin belajar untuk kehidupan masa depan. Guru di LPKA harus dapat bersikap sebagai manager. $^{116}$

3. Lembaga Pembinaan Khusus Anak Kelas 1 Tangerang dan Pendidikan Non Formal.

${ }^{113}$ Veithzal Rivai Zaenal dan Fauzi Bahar, Islamic Education Mangement Dari Teori Ke Praktik, Mengelola Pendidikan Secara Profesional Dalam Perspektif Islam, (Depok: Rajagrapindo Persasada, 2013), h. 80.

${ }^{114}$ Pengamatan langsung dari Observasi penulis ke Lembaga Pembinaan Khusus Anak Klas I Tangerang, Rabu, 21 Desember 2016

${ }^{115}$ Wawancara dengan Sino, SH, MA, Kepala SMP Istimewa, Lembaga Pembinaan Khusus Anak Klas I Tangerang Rabu, 21 Desember 2016.

${ }^{116}$ Veithzal Rivai Zaenal dan Fauzi Bahar, Islamic Education Mangement... Op.cit., h. 371-372. Guru dapat bersikap seperti manajer; maka guru sebagai manager dapat melakukan beberapa hal: 1) memberikan keterangan yang perlu untuk melakukan pekerjaan. 2) memberikan kesempatan umpan balik secara teratur. 3) meminta masukan dari karyawan dan melibatkan mereka di dalam keputusan yang memengaruhi pekerjaan mereka.

4) membuat saluran komunikasi yang mudah dipergunakan sehingga karyawan dapat mempergunakan untuk mengutarakan pertanyaan/kekhawatiran mereka dan memperoleh jawaban. 5) belajar dari karyawan itu sendiri apa yang memotifasi mereka. 6) memberikan sikap saling menghargai, 7) memberikan selamat secara pribadi, 8) menjaga hubungan baik antara guru dengan orang-orang yang mereka bawahi. 9) menulis memo secara pribadi kepada mereka tentang hasil kenerja mereka yang baik secara umum. 10) menyelenggarakan pertemuan-pertemuan pembentukan moril. 11) memberikan penghargaan 12) memberikan sarana kerja yang terbaik. 
ISTIGHNA, Vol. 1, No 1, Januari 2018 P-ISSN 1979-2824

Homepage: http://e-journal.stit-islamic-village.ac.id/index.php/istighna

Gunaldi Ahmad Hakikat Pendidikan di Lembaga Pembinaan Khusus Anak

"Dalam perspektif pendidikan non formal kegiatan telah disediakan oleh para pengelola Lembaga Pembinaan Anak Tangerang, seperti menjahit, berkebun, berternak dan keterampilan las karbit. kegiatan lainnya adalah kepramukaan. Pendidikan non formal di LPKA dilakukan di lapangan, bengkel kerja, di mesjid, dan sarana ibadah lainnya. ${ }^{117}$ Dalam pengamatan langsung penulis di LPKA Tangerang tahun 2016 penulis menyaksikan ada tempat latihan kerja lain seperti penulis juga menyaksikan hal lain seperti kegiatan kegiatan montir sepeda motor, latihan mencukur rambut.

Secara umum pendidikan formal sangat dominan dalam kehidupan di Lembaga Pembinaan Khusus Anak. Dari hasil penelitian yang telah dipublikasikan pada tahun 1998 oleh Wagiati Soetodjo dalam bentuk tabel jadwal kegiatan narapidana anak di LPKA Klas 1 Tangerang:

\begin{tabular}{|c|c|c|c|}
\hline No & Hari dan Jam & Kegiatan & Petugas \\
\hline 1 & $\begin{array}{l}\text { Senin s/d Minggu } \\
05.00 \mathrm{~s} / \mathrm{d} 06.30\end{array}$ & $\begin{array}{l}\text { Bangun tidur, } \\
\text { merapikan tempat } \\
\text { tidur, shalat subuh } \\
\text { berjamaah di mushalla } \\
\text { bagi yang beragama } \\
\text { Islam, bersih-bersih } \\
\text { kamar/ halaman/ } \\
\text { mandi/ makan pagi } \\
\text { dan serah terima } \\
\text { penjaga }\end{array}$ & \\
\hline 2 & $\begin{array}{l}\text { Senin s/d Minggu } \\
06.30 \mathrm{~s} / \mathrm{d} 07.00\end{array}$ & $\begin{array}{l}\text { Apel kerja atau apel } \\
\text { sekolah kerja seperti: } \\
\text { pertukangan kayu, } \\
\text { menjahit, pembuatan } \\
\text { batako, pertanian dan } \\
\text { peternakan. }\end{array}$ & \\
\hline
\end{tabular}

${ }^{117}$ Wagiati, Soetodjo, Hukum Pidana Indonesia, (Bandung: Reflika Aditama, 2006),h. 116- 
ISTIGHNA, Vol. 1, No 1, Januari 2018 P-ISSN 1979-2824

Homepage: http://e-journal.stit-islamic-village.ac.id/index.php/istighna

Gunaldi Ahmad Hakikat Pendidikan di Lembaga Pembinaan Khusus Anak

\begin{tabular}{|c|c|c|}
\hline 3 & $\begin{array}{l}\text { Senin s/d Minggu } \\
07.00 \mathrm{~s} / \mathrm{d} 08.00\end{array}$ & $\begin{array}{l}\text { Olahraga seperti } \\
\text { senam, sepakbola, } \\
\text { atau bola voli. }\end{array}$ \\
\hline 4 & $\begin{array}{l}\text { Senin s/d Minggu } \\
08.00 \mathrm{~s} / \mathrm{d} 12.00\end{array}$ & $\begin{array}{ll}\text { Sekolah } & \text { kerja. } \\
\text { (Kecuali hari } & \text { Jumat } \\
\text { sampai 11.30). } & \end{array}$ \\
\hline 5 & $\begin{array}{l}\text { Senin s/d Minggu } \\
12.00 \mathrm{~s} / \mathrm{d} 12.30\end{array}$ & $\begin{array}{lr}\text { Shalat } & \text { zuhur } \\
\text { berjamaah } & \text { di } \\
\text { mushalla. } & \text { (kecuali } \\
\text { shalat Jumat pulkul } \\
\text { 11.30-12.30. }\end{array}$ \\
\hline 6 & $\begin{array}{l}\text { Senin s/d Minggu } \\
12.30 \mathrm{~s} / \mathrm{d} 13.00\end{array}$ & $\begin{array}{l}\text { Makan siang (kecuali } \\
\text { hari Jumat (makan } \\
\text { siang jam } 11.00\end{array}$ \\
\hline 7 & $\begin{array}{l}\text { Sening s/d Minggu } \\
13.00 \mathrm{~s} / \mathrm{d} 13.30\end{array}$ & $\begin{array}{l}\text { Apel siang / serah } \\
\text { terima penjaga oleh } \\
\text { petugas jaga }\end{array}$ \\
\hline 8 & $\begin{array}{l}\text { Senin dan kamis } \\
14.00 \mathrm{~s} / \mathrm{d} 16.00\end{array}$ & $\begin{array}{l}\text { Pembinaan Rohani } \\
\text { Kristen bagi anak } \\
\text { didik yang beragama } \\
\text { Kristen kecuali bagi } \\
\text { yang beragama Islam } \\
\text { kegiatan dihalaman } \\
\text { dan shalat ashar. }\end{array}$ \\
\hline 9 & $\begin{array}{l}\text { Selasa dan Rabu } \\
14.00 \text { s/d } 16.00\end{array}$ & $\begin{array}{l}\text { Pembinaan Rohani } \\
\text { Islam bagi anak didik } \\
\text { yang beragama Islam. } \\
\text { Kecuali bagi yang } \\
\text { beragama Kristen } \\
\text { kerja di lapangan. }\end{array}$ \\
\hline
\end{tabular}


ISTIGHNA, Vol. 1, No 1, Januari 2018 P-ISSN 1979-2824

Homepage: http://e-journal.stit-islamic-village.ac.id/index.php/istighna

Gunaldi Ahmad Hakikat Pendidikan di Lembaga Pembinaan Khusus Anak

\begin{tabular}{|l|l|l|l|}
\hline 10 & Kamis & $\begin{array}{l}\text { Kesenian (latihan } \\
\text { music band bagi } \\
\text { semua anak didik } \\
\text { pemasyarakatan. }\end{array}$ & $\begin{array}{l}\text { Olah raga (senam, } \\
\text { voli, bola kaki) untuk } \\
\text { semua anak didik. }\end{array}$ \\
\hline 11 & $\begin{array}{l}\text { Jumat } \\
08.00 \mathrm{~s} / \mathrm{d} 11.00\end{array}$ & $\begin{array}{l}\text { Shalat Jumat. } \\
11.00 \mathrm{~s} / \mathrm{d} 12.30\end{array}$ & Pramuka (untuk \\
& $\begin{array}{l}14.00 \mathrm{~s} / \mathrm{d} 16.00 \\
\text { semua anak didik). }\end{array}$ & \\
\hline 12 & $\begin{array}{l}\text { Sabtu s/d Minggu } \\
14.00-16.00\end{array}$ & Nonton TV & \\
\hline 13 & Minggu & Kerja bakti ${ }^{118}$ & \\
\hline
\end{tabular}

Pada tabel di atas para menunjukkan kegiatan harian yang ditulis peneliti terdahulu tahun1998, menurut penulis secara umum tidak mengalami perubahan yang besar dengan saat ini.

Dari agenda harian di atas maka dari hasil wawancara penulis dengan bagian juru bicara LPTKA bahwa khusus kegiatan pendidikan formal, mengkuti aturan Kementerian Pendidikan dan Kebudayaan. Adapun kegiatan belajar mengajar SD Istimewa, SMP Istimewa dan SMK Istimewa LPKA Klas 1 Tangerang belajar dari jam 08.00 s/d 12.00 Wib. Dengan demikian kegiatan harian khusus bagi anak-anak yang mengikuti sekolah dapat berubah. ${ }^{119}$

Dari dua pola pendidikan yang diberikan pendidikan formal dan pendidkan non formal maka sesuai dengan Undang-undang No 11 Tahun

\footnotetext{
${ }^{118}$ Ibid, h. 116-117.

${ }^{119}$ Wawancara dengan dengan Rizal Hamdi, Plh Kepala LPKA Klas 1 Tangerang), Rabu,
} 21 Desember 2016. 
ISTIGHNA, Vol. 1, No 1, Januari 2018 P-ISSN 1979-2824

Homepage: http://e-journal.stit-islamic-village.ac.id/index.php/istighna

Gunaldi Ahmad

Hakikat Pendidikan di Lembaga Pembinaan Khusus Anak

2012 tentang Sistem Peradilan Anak, maka pendidikan non formal dapat diikuti semua anak penghuni LPKA. Sedangkan dalam hal pendidikan formal secara substansi terbatas. Hal ini disebabkan penghuni LPKA diberi hak untuk memilih mengikuti kegiatan pendidikan formal atau tidak karena menurut atuarn Undang-undang Sistem Pidana Anak mengikuti pendidikan formal bagi "Anak" sebutan anak yang berurusan dengan hukum di LPKA merupakan sebuah hak.

\section{Hakikat Pendidikan Di Lembaga Pembinaan Khusus Anak}

Pendidikan bertujuan untuk menciptakan perubahan tingkah laku dari manusia. Pendidikan secara harus dapat memberikan perubahan dari sisi pengetahuan, tindakan, hasil serta terciptanya kehidupan bersama bermasyarakat yang baik. Orang Yunani tempo dulu menyebutkan bahwa pendidikan itu ialah pertolongan kepada manusia agar menjadi manusia. Menurut pandangan orang Yunani kuno pendidikan manusia memiliki kemampuan untuk mengendalikan diri, cinta tanah air dan berpengetahuan. ${ }^{120}$

Penulis berpendapat bahwa pembicaraan hakikat pendidikan sangat penting. Hakikat Pendidikan tidak bisa diperoleh secara instan. Hakikat pendidikan itu baru bisa diperoleh dengan proses. Penulis menyebutnya "proses lahir dan batin." Proses lahir penulis maksudkan adalah Proses belajar mengajar. Proses belajar mengajar merupakan sebuah laporan nyata dari sebuah keberhasilan dari pencapaian dari tujuan pembelajaran (tujuan intraksional). Menurut Bloom tujuan instraksional kognitif (otak dan intelektualitas), tujuan instraksional afektif (rohani, kelakuan/budi pekerti) dan tujuan instraksional psikomotorik (jasmani atau gerakan jasmani). Dalam proses pembelajaran seseorang guru harus mampu mentransfer ilmu. Transfer adalah pemindahan atau penggunaan hasil pelajaran pada situasi baru. Guru yang baik seringkali bertanya pada dirinya sendiri: pokok pelajaran apa, metode apa yang paling berguna untuk murid-murid saya? ${ }^{121}$

${ }^{120}$ Ahmad Tafsir, Filsafat Pendidikan Islami, ... Op.cit., h. 32-40.

${ }^{121}$ Heinz Kock, Saya Guru Yang Baik !?, (Jakarta: Penerbit Yayasan Kanisius, tt), h. 2651. Dalam capain tujuan instaksional kognitif seorang siswa akan mencapatkan kompleksitas capaian yakni pertama pengetahuan, pengetahuan mengandung ingatan akan kekhsusan dan keumuman, ingatan akan cara dan proses atau adat istiadat, struktur atau latar belakang. Kedua, pengertian, tingkat pengertian yang lebih rendah siswa harus mengerti dan memahami hal-hal yang 
ISTIGHNA, Vol. 1, No 1, Januari 2018 P-ISSN 1979-2824

Homepage: http://e-journal.stit-islamic-village.ac.id/index.php/istighna

Gunaldi Ahmad

Hakikat Pendidikan di Lembaga Pembinaan Khusus Anak

Penulis berpendapat bahwa hakikat pendidikan di Indonesia termasuk di Lembaga Pembinaan Khusus Anak harus memiliki tiga nilai filosofis, dalam hal ini Veitzal Rivai Zaenal dan Fauzi Bahar menjelaskan ada ada tiga landasan filosofis pendidikan di Indonesia, yakni: pertama Bhineka Tunggal Ika: Pengakuan kebhinekaan antar sesama manusia yang mengemban misi tunggal sebagai wakil (khalifah) Tuhan di muka bumi. Kedua; Pancasila. Ketiga, pendidikan itu mengandung 4 pilar UNESCO yakni, "learning to know, learning to do, learning to be, dan learning to live together" (pendidikan untuk ilmu pengetahuan, pendidikan untuk dapat melakukan sesuatu, pendidikan untuk membuta seseorang menjadi apa yang ia inginkan, dan pendidikan agar seseorang mampu hidup bermasyarakat). ${ }^{122}$

Dari pemaparan di atas menurut penulis hakikat pendidikan baru bisa lebih sempurna diperoleh jika nilai-nilai spiritual diterapkan kepada peserta didik. Nilai-nilai spiritual secara terstruktur telah dilembagakan dalam mata pelajaran PAI. Di pendidikan formal mata pelajaran PAI diajarkan kepada siswa di tingkat SD, SLTP dan SLTA, termasuk di semua Lembaga Pembinaan Anak (LPTK) di Indonesia. Pemberian mata pelajaran PAI ini akan memberikan garansi bahwa pendidikan formal di Indonesia sesuai dengan kemaslahatan umum dalam sudut pandang Islam.

Dengan demikian pelaksanaan lembaga pendidikan formal di dalam situasi apapun idealnya harus memenuhi hakikat pendidikan itu sendiri, terpenuhinya aturan-aturan pendidikan secara umum. Dengan demikian guru-guru professional sangat dibutuhkan. Yang sangat pernting siswa di LPKA mampu mengendalikan diri dalam kehidupannya lebih baik di dalam LPKA dan nanti

diberitahukan. Siswa harus dapat menggunakan bahan atau pikiran yang diberikan. Tidak usah menghubungkan itu dengan bahan atau pikiran yang lain. Ketiga penggunaan. Penggunaan maksudnya abstraksi dalam situasi tertentu. Menggunakan suatu kemampuan pada suatu hal yang baru. Keempat analisis, analisis adalah membagikan suatu berita dalam unsurnya supaya urutan pikiran menjadi jelas dan/atau hubungan-hubungan antara pemikirannya menjadi jelas. Analisis ini harus menjelaskan komunikasi, harus membuktikan bagaimana komunikasi itu tersusun. Keenam sintesis. Penyimpulan dari unsur-unsur dan bagian-bagian pada suatu keseluruhan dengan struktur dan pola yang sebelumnya tidak diketahui dan keenam petimbangan, pertimbangan merupakan pertimbangan atas nilai bahan dan cara untuk hal-hal tertentu. Pertimbangan kuantitatif, kualitatif apakah bahan dan cara tersebut cocok dengan kriteria tertentu.

${ }^{122}$ Veithzal Rivai Zaenal dan Fauzi Bahar, Islamic Education Mangement ..., Op.cit., h. 273 
ISTIGHNA, Vol. 1, No 1, Januari 2018 P-ISSN 1979-2824

Homepage: http://e-journal.stit-islamic-village.ac.id/index.php/istighna

Gunaldi Ahmad Hakikat Pendidikan di Lembaga Pembinaan Khusus Anak

selanjutnya saa keluar dari Lembaga Pembinaan Khusus Anak. Oleh karena itu bagi "Anak" untuk menjaga kualitas mental mereka pendidkan formal dan non formal harus terintegrasi kemampuan ilmu pengetahuan dan pembagunan sikap mental dalam hal pengendalian diri.

\section{Penutup}

Dari penelitian penulis dapat disimpulkan bahwa pendidikan yang berlaku di Lembaga Pembinaan Khusus Anak sama pemberlakuannya dengan pendidikan formal, SD, SMP, SLTA lainnya di luar lembaga. Waktu proses belajar mengajar mereka sekolah sama. Serta Hal yang perlu diperhatikan lagi adalah pemberlakuan sertifikasi guru bagi yang mengajar di LPKA, guru-guru lembaga pembinaan khusus anak juga memiliki sertifikasi. Secara umum anak di lembaga pembinaan khusus anak mendapatkan pendidikan yang layak sesuai amanah pembukaan undang-undang yaitu mencerdaskan kehidupan bangsa. Demikian pula proses pendidikan di LPKA memberikan implementasi Undang-undang Sistem Pendidikan Nasional. Tempat pendidikan formal yang sudah diselenggarakan di LPKA Klas 1 Tangerang harus ditingkatkan dengan penambahan sarana dan prasarana yang memadai. Dalam sisi hakikat pendidikan itu sendiri, pendidikan yang dilakukan di LPKA mampu memberikan jaminan perbaikan akhlak dari anak didik pemasyarakatan.

\section{DAFTAR PUSTAKA}

Fokusmedia, Undang-undang Sisdiknas (Sistem Pendidikan Nasional) (Bandung: Fokusmedia, 2010)

Hamdi, Rizal, Wawancara dengan Plh Kepala LPKA Klas 1 Tangerang), Rabu, 21 Desember 2016

Kock, Heinz, Saya Guru Yang Baik!? (Jakarta: Penerbit Yayasan Kanisius, tt.) Al-Rasyidin dan Samsul Nizar, Pendekatan Teoritis dan Praktis Filsafat Pendidikan Islam, (Ciputat: Rajawali Press, 2005), Cet. Ke-2.

Redaksi Sinar Grafika, Undang-undang Perlindungan Anak (UU No. 23 Tahun 2002), (Jakarta Sinar Grafika, 2003) 
ISTIGHNA, Vol. 1, No 1, Januari 2018 P-ISSN 1979-2824

Homepage: http://e-journal.stit-islamic-village.ac.id/index.php/istighna

Gunaldi Ahmad Hakikat Pendidikan di Lembaga Pembinaan Khusus Anak

--------, Undang-Undang Peradilan Anak, No. 3 Tahun 1997, (Jakarta: Sinar Grafika, 1997)

Soetodjo, Wagiati, Hukum Pidana Indonesia, (Bandung: Reflika Aditama, 2006)

Tafsir, Ahmad Filsafat Pendidikan Islami, Integrasi Jasman, Rohani dan Kalbu Memanusiakan Manusia, (Bandung: Remaja Rosdakarya, 2006)

Zaenal, Veithzal Rivai dan Fauzi Bahar, Islamic Education Mangement Dari Teori Ke Praktik, Mengelola Pendidikan Secara Profesional Dalam Perspektif Islam, (Depok: Rajagrapindo Persasada, 2013)

\section{Data Online:}

Blogspot.co.id, Lembaga Pembinaan Khusus Anak Klas I Tangerang, Selasa 12 April 2016.

www Hukum Online com, Undang-undang No 11 Tahun 2012 Tentang Sistem Peradilan Pidana Anak, accses, 2 Juli 2018.

\section{Wawancara:}

Wawancara dengan Sino, Kepala SMP Istimewa, Lembaga Pembinaan Khusus Anak Klas I Tangerang.

Wawancara dengan Hamdi, Plh Kepala LPKA Klas 1 Tangerang), Rabu, 21 Desember 2016.

\section{Observasi:}

Pengamatan langsung dari Observasi penulis ke Lembaga Pembinaan Khusus Anak Klas I Tangerang, Rabu, 21 Desember 2016 